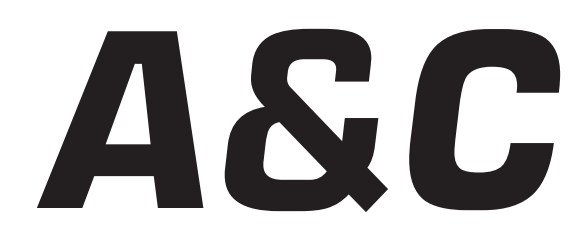

Revista de Direito Administrativo \& Constitucional

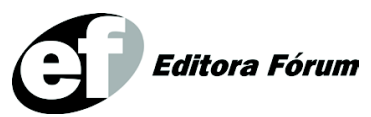

ISSN 1516-3210 


\section{A\&C REVISTA DE DIREITO ADMINISTRATIVO E CONSTITUCIONAL}

IPDA

Instituto Paranaense

de Direito Administrativo

Direção Geral

Romeu Felipe Bacellar Filho

Direção Editorial

Paulo Roberto Ferreira Motta

Direção Executiva

Emerson Gabardo

Conselho de Redação

Edgar Chiuratto Guimarães

Adriana da Costa Ricardo Schier

Célio Heitor Guimarães

\section{Conselho Editorial}

Adilson Abreu Dallari

Alice Gonzáles Borges

Carlos Ari Sundfeld

Carlos Ayres Britto

Carlos Delpiazzo

Cármen Lúcia Antunes Rocha

Celso Antônio Bandeira de Mello

Clèmerson Merlin Clève

Clóvis Beznos

Enrique Silva Cimma

Eros Roberto Grau

Fabrício Motta

Guilhermo Andrés Muñoz (in memoriam)

Jaime Rodríguez-Arana Muñoz

Jorge Luís Salomoni

José Carlos Abraão
José Eduardo Martins Cardoso
José Luís Said
José Mario Serrate Paz
Juan Pablo Cajarville Peruffo
Juarez Freitas
Julio Rodolfo Comadira
Luís Enrique Chase Plate
Lúcia Valle Figueiredo
Manoel de Oliveira Franco Sobrinho
(in memoriam)
Marçal Justen Filho
Marcelo Figueiredo
Márcio Cammarosano
Maria Cristina Cesar de Oliveira

Nelson Figueiredo

Odilon Borges Junior

Pascual Caiella

Paulo Eduardo Garrido Modesto

Paulo Henrique Blasi

Paulo Neves de Carvalho (in memoriam)

Paulo Ricardo Schier

Pedro Paulo de Almeida Dutra

Regina Maria Macedo Nery Ferrari

Rogério Gesta Leal

Rolando Pantoja Bauzá

Sérgio Ferraz

Valmir Pontes Filho

Yara Stropa

Weida Zancaner

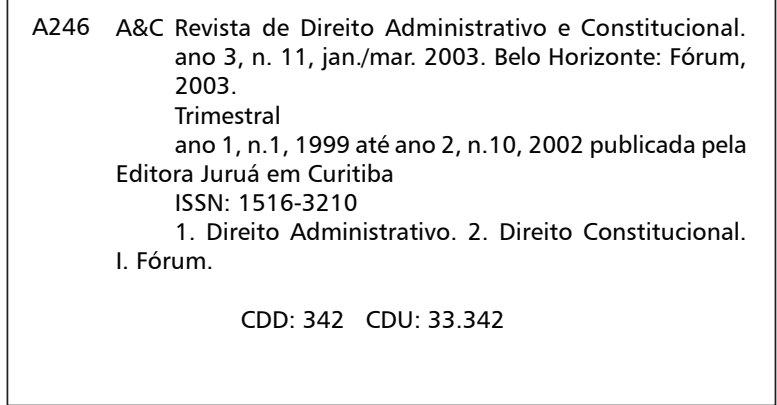

(C) Editora Fórum Ltda. 2007

Todos os direitos reservados. É proibida a reprodução total ou parcial, de qualquer forma ou por qualquer meio eletrônico ou mecânico, inclusive através de processos xerográficos, de fotocópias ou de gravação, sem permissão por escrito do possuidor dos direitos de cópias (Lei nº 9.610, de 19.02.1998).

Editora Fórum Ltda

Av. Afonso Pena, 2770 - 15\%16ª andar - Funcionários

CEP 30130-007 - Belo Horizonte/MG - Brasil

Tel.: 08007043737

Internet: www.editoraforum.com.br

e-mail: editoraforum@editoraforum.com.br
Editor responsável: Luís Cláudio Rodrigues Ferreira Projeto gráfico e diagramação: Luis Alberto Pimenta Revisora: Olga M. A. Sousa

Pesquisa jurídica: Fátima Ribeiro - OAB/MG 74868

Bibliotecária: Alessandra Rodrigues da Silva CRB 2778/MG 6 ${ }^{\text {a Região }}$

Os conceitos e opiniões expressas nos trabalhos assinados são de responsabilidade exclusiva de seus autores.

Impressa no Brasil / Printed in Brazil

Distribuída em todo Território Nacional 


\title{
Democracia deliberativa e jurisdição constitucional
}

\author{
Heloísa da Silva Krol* \\ Bacharel em Direito pela Universidade Federal do Paraná. Mestranda em Direito do Estado na \\ Universidade Federal do Paraná. Bolsista da CAPES. Advogada.
}

Palavras-chave: Direito. Moral. Democracia deliberativa. Jurisdição constitucional.

Sumário: 1 Considerações iniciais - 2 Justificativas da democracia - 3 A democracia deliberativa - 4 O papel da jurisdição constitucional - 5 Considerações finais - Referências

\section{Considerações iniciais}

Com efeito, afirma-se que a característica fundamental da modernidade é o advento da revolução democrática. ${ }^{1}$ Ainda, verifica-se que há um compromisso com a sociedade democrática liberal por parte de autores liberais, comunitaristas e crítico-deliberativos. Ou seja, todos defendem as instituições do liberalismo político (império da lei, separação dos poderes e direitos fundamentais) e a democracia, representada pela soberania popular e pela regra da maioria, mesmo que com algumas variações importantes nas respectivas formulações. ${ }^{2}$

O presente artigo concentra-se na abordagem da vertente democrático-deliberativa. Nos termos dessa proposta, o papel da constituição em sociedades marcadas pelo fato do pluralismo razoável é o de assegurar as condições para deliberação democrática e para sua promoção.

Diretamente relacionada com essa questão há uma ponderação interessante na obra de Carlos Santiago Nino, autor cuja obra tem especial importância para este ensaio. Ao analisar a conexão direta entre direito, moral e política, Nino deparou-se com o paradoxo do caráter supérfluo do direito. Assim, o autor expõe a seguinte indagação: se as normas jurídicas não constituem por si mesmas razões para justificar decisões na medida em que devem ser justificadas com base em princípios morais, qual é então a relevância das normas jurídicas? ${ }^{3}$

Não obstante Nino defenda uma relação forte entre direito e moral,

\footnotetext{
*Email: helokrol@pop.com.br

MOUFFE. O regresso do político, p. 24.

2 CITTADINO. Pluralismo, direito e justiça distributiva: elementos da filosofia constitucional contemporânea, p. 5.

3 NINO. Ética y derechos humanos: un ensayo de fundamentación, p. 370.
} 
reconhece como evidente que uma coincidência plena entre exigências morais e normas jurídicas é utópica. As autoridades estão sujeitas a desvios morais, deliberados ou involuntários e, nesses termos, surgem mais duas questões: a primeira refere-se ao sistema de governo que minimiza a probabilidade de desvios morais e, a segunda, trata da possibilidade de existir um sistema de governo que garanta certa obrigatoriedade moral para suas normas jurídicas ainda quando o conteúdo destas envolva erros morais. ${ }^{4}$

Nino aponta a democracia como resposta a ambas as perguntas. ${ }^{5}$ Portanto, devido à importância da democracia, tida como fundamento das normas jurídicas, torna-se necessário analisar as justificativas correntes da democracia e também da possibilidade de otimizar seu potencial a partir da noção de democracia deliberativa.

\section{Justificativas da democracia}

Poder-se-ia indagar se a democracia realmente pode ser considerada imprescindível afirmando-se, por exemplo, que uma ditadura que se preste à realização de direitos fundamentais teria o mesmo valor que uma sociedade democrática. Ou ainda, que seria preferível um regime ditatorial no qual se respeitassem determinados direitos a uma democracia em que esses permanecessem como promessas não cumpridas.

Contudo, sustenta-se, com base na doutrina de Nino, que a democracia possui um valor epistêmico para acessar a decisões moralmente corretas. $^{6}$

Na obra Ética y derechos humanos, Nino analisa as justificativas correntes da democracia. ${ }^{7}$ A primeira enfocada é a noção de que a democracia é uma expressão da soberania popular. Trata-se da abordagem mais tradicional, pois se sustenta no argumento de que a democracia é a única

\footnotetext{
NINO. Ética y derechos humanos: un ensayo de fundamentación, p. 370.

NINO. Ética y derechos humanos: un ensayo de fundamentación, p. 371.

NINO. La Constitución de la democracia deliberativa, p. 168.

7 Também na obra La constitución de la democracia deliberativa, Nino preocupa-se de analisar as diversas justificativas da democracia dividindo-as em dois grupos. No primeiro, entram as teorias que reservam um âmbito para o funcionamento da política democrática dentro do qual assuntos morais não estariam em jogo (teorias utilitaristas, elitistas, pluralistas e conseqüêncialistas). Consideram como fato os interesses e preferências das pessoas e supõe que as pessoas atuam com base nestes interesses inalteráveis. Trata-se de um enfoque pessimista que pressupõe uma concepção das facções como auto-interessadas e como uma ameaça aos interesses individuais. A segunda linha de teorias adota um enfoque exatamente oposto quanto à capacidade para transformar as preferências e as inclinações das pessoas e, assim, insere a democracia no âmbito da moral (teorias de soberania popular, perfeccionistas e enfoques dialógicos). Outro ponto em que discordam essas concepções consiste na primeira adotar um enfoque liberal de primazia dos direitos em relação à democracia, ao passo que a segunda enfatiza a democracia (NINO. La Constitución de la democracia deliberativa, p. 102-143).
} 
forma de governo em que o povo permanece soberano, governando-se a si mesmo. ${ }^{8}$

Contudo, o problema dessa linha argumentativa é justamente definir o conceito de povo, ${ }^{9}$ tendo em vista que se trata de palavra ambígua que pode ter ao menos quatro significados. ${ }^{10}$

Com efeito, a primeira acepção identifica povo como "todos e cada um dos indivíduos que integram o grupo social”. Porém essa idéia inviabiliza a democracia, pois somente a unanimidade poderia satisfazer o ideal de autogoverno e essa exigência acabaria por favorecer os indivíduos que apóiam o status quo na medida em que o voto contrário de um impossibilita qualquer alteração. ${ }^{11}$

Devido à inviabilidade da unanimidade, afirma, a segunda alternativa, que povo significa a maioria (analisada aqui como maioria que defende uma mesma opinião). Nino aponta que com essa interpretação o ideal da soberania popular acaba sendo pouco plausível, pois é absurdo afirmar que há autogoverno quando a decisão que se impõe a todos surge de uma subclasse de um grupo relevante. Note-se, porém, que Nino não está defendendo que o critério majoritário não pode ser justificável, mas sim que não se pode fundamentar o governo da maioria com base na afirmação de que assim se materializa o ideal de autogoverno do povo. ${ }^{12}$

A terceira alternativa é identificar o povo com um setor da população total que se distingue por certo traço relevante que não consiste no mero fato de que seus membros têm opiniões coincidentes quanto a determinados assuntos (por exemplo, quando se discrimina com base em critérios raciais ou sócio-econômicos). Trata-se de posição distinta da anterior tendo em vista o critério discriminador, mas que pode ser refutada pelas mesmas razões. ${ }^{13}$

Por fim, há quem identifique o povo como uma espécie de entidade supra-individual ou coletiva, sustentando que existe uma vontade geral ou popular dirigida ao bem comum (concepção de Rousseau). Segundo Nino, nem essa concepção consegue salvar o ideal de governo do povo pelo povo como justificativa da democracia, pois o povo não constitui

\footnotetext{
8 NINO. Ética y derechos humanos: un ensayo de fundamentación, p. 371.

9 Afirma-se, inclusive, que todas as razões do exercício democrático do poder e todas as razões da crítica da democracia dependem desse ponto de partida (MUELLER. Quem é o povo? A questão fundamental da democracia, p. 47).

10 NINO. Ética y derechos humanos: un ensayo de fundamentación, p. 372.

${ }^{11}$ NINO. Ética y derechos humanos: un ensayo de fundamentación, p. 373.

${ }^{12}$ NINO. Ética y derechos humanos: un ensayo de fundamentación, p. 374.

${ }^{13}$ NINO. Ética y derechos humanos: un ensayo de fundamentación, p. 375.
} 
um centro de autoconsciência e não é portador de interesses não redutíveis a certos indivíduos. ${ }^{14}$

Outra tentativa é justificar a democracia como o governo que conta com o consentimento dos governados. Já que a aprovação geral não é viável, o consentimento poderia ser suficiente para justificar a democracia. A idéia é que a participação no processo democrático, ainda que para expressar desaprovação, pode implicar consentimento com o resultado desse processo. ${ }^{15}$

Entretanto, o consenso só pode existir quando a participação é voluntária e a voluntariedade da participação exige que o voto não seja obrigatório. Ademais, exige que a obrigação resultante do processo só se aplique aos que efetivamente participaram, não aos que se omitiram. Portanto, a idéia do consenso dos governados não justifica a democracia, pois no fundo essa justificativa leva praticamente a mesma exigência de aprovação unânime já analisada. ${ }^{16}$

Nino também analisa outras hipóteses justificadoras da democracia, tais como a que sustenta que a democracia consagra a igualdade e se conecta a um procedimento eqüitativo; as de índole contratualista e as consequencialistas. Mas considera todas insuficientes. ${ }^{17}$

Assim, Nino enfatiza que a democracia é defensável por ser um sucedâneo do discurso moral. ${ }^{18}$ Trata-se, portanto, de um discurso moral regulamentado que preserva em maior grau que qualquer outro sistema de decisões os traços do discurso moral originário. ${ }^{19}$

Nesses termos, tem-se que o discurso moral é uma técnica para convergir em ações e atitudes com base na adoção livre e compartilhada dos mesmos princípios que guiam essas ações e atitudes. $\mathrm{O}$ discurso dirigido a esse fim consiste no exame da adequação de princípios que pretendem justificar comportamentos frente a certas condições que estão fixadas por regras procedimentais implícitas no discurso (ex. a que diz que todo princípio deve ser aceitável a partir de um ponto de vista que considere de

\footnotetext{
${ }^{14}$ NINO. Ética y derechos humanos: un ensayo de fundamentación, p. 377.

${ }^{15}$ NINO. Ética y derechos humanos: un ensayo de fundamentación, p. 378.

${ }^{16}$ NINO. Ética y derechos humanos: un ensayo de fundamentación, p. 381.

${ }^{17}$ NINO. Ética y derechos humanos: un ensayo de fundamentación, p. 381-386.

${ }^{18}$ Aqui, a teoria de Nino se aproxima da teoria do caso especial de Alexy. Para este autor, o discurso jurídico é um caso especial de discurso prático geral, tendo em vista: a) a referência das discussões jurídicas a questões práticas; b) a discussão dessas questões sobre o prisma da correção e c) que a discussão jurídica se faz sob condições de limitações (vinculação ao direito vigente). (ALEXY. Teoria da argumentação jurídica: a teoria do discurso racional como teoria da justificação jurídica, p. 210-211).

${ }^{19}$ NINO. Ética y derechos humanos: un ensayo de fundamentación, p. 388.
} 
forma imparcial todos os interesses envolvidos). Observe-se, todavia, que essa técnica não garante a priori resultados únicos para todo caso concebível e tampouco assegura resultados definitivos. ${ }^{20}$

Essas considerações fundamentam a adoção de um construtivismo epistemológico, em oposição ao ontológico, ${ }^{21}$ pois os princípios morais se inferem pela via de argumentos baseados nos pressupostos e regras procedimentais do discurso moral. Nesses termos, pode-se afirmar que o discurso é constitutivo dos princípios, mas não que os princípios se constituem como resultado do discurso, pois mesmo sem esperar o resultado qualquer participante pode defender princípios morais devido a sua relação com os pressupostos do discurso. ${ }^{22}$

O resultado do discurso tem um valor epistemológico em razão do efeito positivo que tem a discussão para detectar falhas no conhecimento e na racionalidade e, sobretudo, na equivalência funcional que há entre consenso unânime entre todos os interesses e imparcialidade. Assim, é possível presumir que o resultado do discurso se aproxima de uma solução correta. ${ }^{23}$

Outra função do discurso moral é a função prática de permitir a superação de conflitos e que se alcance a cooperação. Contudo, em muitos casos o discurso moral não é operativo, tendo em vista que há pessoas que se negam a participar e preferem outros métodos como a força; há pessoas que simulam participar, que não cumprem o compromisso de atuar conforme os princípios. Ainda, pode ocorrer que no momento em que a decisão coletiva é relevante não se logre o consenso entre todos os interessados. ${ }^{24}$

Para superar essa última limitação do discurso moral, deve-se abandonar seu caráter temporalmente ilimitado e fixar oportunidades para uma decisão obrigatória, sendo que isso leva a outra modificação, que é a substituição da exigência de consenso unânime pela aprovação

\footnotetext{
${ }^{20}$ Nesse ponto, Nino procura diferenciar sua tese da de Habermas e de Ackerman, que sustentam que os princípios morais válidos são aqueles que resultam de uma discussão real submetida a certas condições (construtivismo ontológico). Para Nino, a fragilidade do construtivismo ontológico consiste na incapacidade de explicar em que consiste a discussão que conduz ao estabelecimento dos princípios morais (NINO. Ética y derechos humanos: un ensayo de fundamentación, p. 389).

${ }^{21}$ Cuja tese consiste em que os princípios morais se constituem como resultado de uma discussão real.

22 NINO. Ética y derechos humanos: un ensayo de fundamentación, p. 390

${ }^{23}$ NINO. Ética y derechos humanos: un ensayo de fundamentación, p. 390

${ }^{24}$ NINO. Ética y derechos humanos: un ensayo de fundamentación, p. 390.
} 
majoritária. ${ }^{25}$

Mas esses desvios pragmáticos não implicam o abandono das demais exigências como a de que as decisões devem estar justificadas com base nos princípios que satisfazem as condições formais do discurso moral (escutar os argumentos a favor e contra, que toda pessoa moral deve ser considerada fonte potencial de tais argumentos, que todos devem participar da decisão coletiva, entre outras). ${ }^{26}$

Nino observa que quando submetemos o discurso moral ao regimento indicado, temos um sucedâneo do discurso originário que é o sistema democrático de decisões. O que justifica esse procedimento é o fato de tender a produzir resultados que se aproximam mais do requisito de imparcialidade. Mesmo o requerimento de simples maioria promove um processo de negociação que impulsiona a imparcialidade. ${ }^{27}$

Portanto, a democracia tem valor epistemológico por ser um bom método para alcançar o conhecimento moral, posto que inclui, como componentes essenciais, tanto a discussão como a conformidade majoritária, levando ao mais próximo possível da verdade moral. ${ }^{28}$

\section{A democracia deliberativa}

Há diversas formas de conceber a democracia. ${ }^{29}$ Recentemente, tem-se enfatizado a democracia deliberativa como uma forma que otimiza os preceitos democráticos. ${ }^{30}$ Conforme definição de Nino, trata-se de uma concepção dialógica que concebe a política e a moral como interconectadas e atribui valor à democracia na moralização das preferências pessoas. A partir dessa concepção, o valor na democracia reside na sua natureza epistêmica em relação à moralidade. ${ }^{31}$

A democracia deliberativa valoriza o "momento comunicativo e dialógico que se instaura quando governantes e cidadãos procuram justi-

\footnotetext{
${ }^{25}$ NINO. Ética y derechos humanos: un ensayo de fundamentación, p. 391.

${ }^{26}$ NINO. Ética y derechos humanos: un ensayo de fundamentación, p. 392.

${ }^{27}$ NINO. Ética y derechos humanos: un ensayo de fundamentación, p. 393-396.

${ }_{28}^{2}$ NINO. Ética y derechos humanos: un ensayo de fundamentación, p. 397.

${ }^{29}$ Sergio Fernando Moro aponta algumas dessas concepções: democracia como possibilidade de destituição do governo sem derramamento de sangue (Karl Popper); conceito de democracia como indissociável do princípio da igualdade (Ronald Dworkin), bem como do conceito de direitos fundamentais (Alain de Touraine) e a concepção recorrente que a identifica como governo do povo (MORO. Jurisdição constitucional como democracia, p. 82-83).

${ }^{30}$ Cass Sunstein relata que a democracia deliberativa já foi defendida no período fundacionista dos Estados Unidos e que nos últimos anos tem havido um extraordinário ressurgimento do interesse pela democracia deliberativa (SUNSTEIN. Prefacio. In: GARGARELLA, Roberto. La justicia frente al gobierno: sobre el carácter contramayoritario del poder judicial, p. 7-8).
} 
ficar seus pontos de vista sobre as questões de interesse público". ${ }^{32}$

Parte-se do pressuposto de que todos devem ser tratados como iguais e de que ninguém tem conhecimento suficiente para decidir sozinho em nome de todos e, assim, sustenta-se que é necessário escutar a todos para possibilitar a correção dos equívocos. Em outros termos, reconhecese que quanto menos oportunidades existirem para levar adiante o processo de mútua clarificação, mais riscos existiram de se decidir mal, baseado em erros, preconceitos ou falta de informação. ${ }^{33}$

Sugere-se, portanto, que os problemas coletivos sejam discutidos coletivamente caso se pretenda adotar decisões que tratem a todos de forma imparcial e inclusiva, assegurando a possibilidade de intervenção de todos os potencialmente afetados pela decisão em jogo. ${ }^{34}$

Uma das idéias fundamentais da democracia deliberativa é compreender a democracia para além da prerrogativa majoritária de decidir sobre questões políticas. Dessa forma, enfatiza-se o debate público no qual diversas posições embasadas em diferentes concepções morais, filosóficas e religiosas se confrontam. ${ }^{35}$ Mas, note-se, que a concepção apenas evidencia a idéia de deliberação, mas não se restringe a ela na medida em que envolve outras atividades como educação política, organização social, mobilização. ${ }^{36}$

Outra nota distintiva é a exigência de prestação de contas, pois muitas vezes é inviável uma participação direta na política. Portanto, a democracia deliberativa não se confunde com a democracia direta, ${ }^{37}$ embora possa incrementar os mecanismos de participação direta e também a própria democracia representativa. ${ }^{38}$

Em linhas gerais, a democracia deliberativa estabelece a incorporação de idéias como a de discussão, publicidade, prestação de contas

\footnotetext{
${ }^{31}$ NINO. La Constitución de la democracia deliberativa, p. 154.

32 SOUZA NETO. Teoria constitucional e democracia deliberativa: um estudo sobre o papel do direito na garantia das condições para a cooperação na deliberação democrática, p. 86.

${ }_{33}$ GARGARELLA. Constitución y democracia. In: ALBANESE, Susana; DALLA VIA, Alberto; GARGARELLA, Roberto et al. (Org.). Derecho constitucional, p.80.

${ }^{34}$ GARGARELLA. Constitución y democracia. In: ALBANESE, Susana; DALLA VIA, Alberto; GARGARELLA, Roberto et al. (Org.). Derecho constitucional, p.82-82. No mesmo sentido, Nino aponta que caso não se obtenha uma ampla participação, a qualidade epistêmica do processo democrático permanece débil (NINO. La Constitución de la democracia deliberativa, p. 222).

35 Aponta, Nino, que o diálogo é o mecanismo através do qual a democracia converte as preferências autointeressadas em preferências imparciais (NINO. La Constitución de la democracia deliberativa, p. 202).

${ }^{36}$ SOUZA NETO. Teoria constitucional e democracia deliberativa: um estudo sobre o papel do direito na garantia das condições para a cooperação na deliberação democrática, p. 87.

${ }^{37}$ Mas se afirma que as expressões mais diretas da vontade cidadã têm mais valor que as mediadas institucionalmente (GARGARELLA. Constitución y democracia. In: Susana Albanese; Alberto Dalla Via;
} 
ou justificação moral, sendo que esta impõe que as decisões públicas possam ser aceitas não só por aqueles que votaram nos representantes, mas por todos os afetados. ${ }^{39} \mathrm{Ou}$ seja, "a democracia deliberativa se caracteriza pelo fornecimento de razões para decidir que possuem a pretensão de convencer também os adeptos de outras doutrinas". ${ }^{40}$

Uma das questões que se coloca quando se fala da pretensão de convencimento, de consenso é que esta noção não permite a exposição de pontos de vistas antagônicos, o que pode retirar o estímulo para a participação na esfera política (espaço de luta e conflito de opiniões). Ademais, o modelo de democracia deliberativa restringiria a deliberação à argumentação racional, que privilegia discursos formais e desapaixonados.

Quanto a esse ponto, Nino responde que a democracia reconhece o papel da negociação das manifestações de emoção, mas mantém para elas um lugar subordinado ao da argumentação. O processo democrático visto como um sucedâneo da prática informal da discussão moral requer que todos os participantes justifiquem suas propostas frente aos demais com argumentos genuínos e válidos. ${ }^{41}$

Portanto, justifica-se a superioridade da democracia deliberativa principalmente frente às concepções pluralistas ${ }^{42}$ por partir do pressuposto que o sistema político valioso é o que promove decisões imparciais. Mas note-se que não se defende a democracia porque ela valoriza o sufrágio,

Roberto Gargarella, et al. (Org.). Derecho constitucional, p.80). Nesse sentido, Nino considera a representação política como um mal necessário, sendo também uma das principais distorções da democracia que lhe afastam do valor epistêmico máximo dado na discussão moral ideal. A representação é necessária devido às impossibilidades concretas da democracia direta, à complexidade dos assuntos políticos atuais e à necessidade de respeitar a autonomia pessoal (NINO. La Constitución de la democracia deliberativa, p. 205).

${ }^{38}$ Cláudio Pereira de Souza Neto exemplifica com o mecanismo do plebiscito. No caso, se a decisão popular não é precedida de um debate aberto, livre e igualitário passa a conter mecanismos tão autoritários quanto os da democracia elitista e também permite a manipulação dos votos (SOUZA NETO. Teoria constitucional e democracia deliberativa: um estudo sobre o papel do direito na garantia das condições para a cooperação na deliberação democrática, p. 87-88).

${ }^{39}$ Gargarella alude ao seguinte exemplo: no âmbito de uma discussão pública, ninguém defenderia o uso de fundos público em benefício próprio, pois a proposta em questão deveria ser aceita por todos (GARGARELLA. La justicia frente al gobierno: sobre el carácter contramayoritario del poder judicial, p. 160-161).

${ }^{40}$ SOUZA NETO. Teoria constitucional e democracia deliberativa: um estudo sobre o papel do direito na garantia das condições para a cooperação na deliberação democrática, p. 89.

${ }^{41}$ NINO. La Constitución de la democracia deliberativa, p. 171. Também Gargarella afirma que a defesa da deliberação na significa sustentar a idéia que esta sempre vai levar a acordos harmônicos, excluindo o conflito (GARGARELLA. Constitución y democracia. In: ALBANESE, Susana; DALLA VIA, Alberto; GARGARELLA, Roberto et al. (Org.). Derecho constitucional, p.84). 
mas sim o processo de reflexão coletiva, enfatizando a discussão pública. ${ }^{43}$

\section{O papel da jurisdição constitucional}

Reconhecida o valor epistêmico da democracia e a superioridade da concepção deliberativa — mesmo que seja como ideal regulador a ser implementado - por incrementar a participação popular, o debate, enfim, as virtudes cívicas, surge uma questão necessária: qual o papel da jurisdição constitucional nesse cenário?

A questão é necessária tendo em vista que a atividade jurisdicional de controle de constitucionalidade não pode ser comparada à atividade legislativa e executiva em termos de legitimidade democrática. ${ }^{44}$ Os juízes não são eleitos pelo povo e, na maioria das vezes, não contam sequer com legitimidade democrática indireta. ${ }^{45}$ Ademais, os tribunais não se submetem a renovação periódica de mandatos e também não se responsabilizam diretamente frente à opinião pública. ${ }^{46}$

Há muita controvérsia quanto a essa questão. Muitos defendem a que a legitimidade da jurisdição decorreria de sua prática decisional ligada ao processo argumentativo. Exige-se que o processo decisório passe por uma dupla exigência de argumentação que assim se manifesta: a) internamente: implica o dever de coerência discursiva, guardando pertinência com o direito vigente; b) externamente: dever se de apresentar racionalmente apta à aceitabilidade dos co-associados. ${ }^{47}$

Não se nega que as exigências impostas pelas teorias da argumentação racionalizam o processo decisório. ${ }^{48}$ No entanto, por si só, não são capazes de delimitar o papel da jurisdição constitucional num cenário

\footnotetext{
42 A concepção pluralista sustenta que o valor da democracia reside no fato de assegurar uma situação de estabilidade na qual nenhum grupo chega a dominar os demais. Ou seja, vincula-se ao fato de que a democracia equilibraria o poder, garantindo a ausência de tiranias institucionais. Também é denominada democracia madisoniana em homenagem ao seu precursor James Madison. Sobre a democracia madisoniana: DAHL. Um prefacio à teoria democrática, p. 13-40.

${ }^{43}$ GARGARELLA. La justicia frente al gobierno: sobre el carácter contramayoritario del poder judicial, p. 158.

44 Tratando da proteção contra as omissões inconstitucionais, Clèmerson Merlin Clève observa que "o órgão jurisdicional não dispõe, parece incontestável, nem de legitimidade e nem de capacidade, para exercer a tarefa de concretização que apenas o jogo político-partidário (com suas dimensões: a interação comunicativa, a disputabilidade intersubjetiva e a dialética oscilando entre o confronte e compromisso parlamentares) pode proporcionar". (CLÈVE. A fiscalização abstrata da constitucionalidade no direito brasileiro, p. 330).

${ }^{45}$ A idéia de legitimidade democrática indireta ou decorrente da jurisdição constitucional apóia-se na forma de designação dos juízes das cortes constitucionais. Muitas vezes os juízes são nomeados pelo órgão executivo, após aprovação do órgão legislativo, como se dá no Brasil quanto aos ministros do Supremo Tribunal Federal (nomeados pelo Presidente da República após aprovação da escolha pela maioria absoluta do Senado Federal). Contudo, nem todos os países adotam esse sistema de escolha e nem todos os magistrados são nomeados dessa forma, não servindo, assim, essa tese, para respaldar a legitimidade da jurisdição constitucional (SAMPAIO. A Constituição reinventada pela jurisdição constitucional, p. 71).

${ }^{46}$ NINO, Carlos Santiago. La Constitución de la democracia deliberativa, p. 259.
} 
marcado pelo pluralismo, que, por sua vez, exige que as decisões sejam tomadas de forma democrática levando em consideração todos os pontos de vista.

O que se pretende discutir é o fundamento e o cabimento de atuações, como a da Corte Warren, ${ }^{49}$ ou mesmo algumas decisões, como a proferida no pelo Superior Tribunal de Justiça brasileiro no Recurso Especial $\mathrm{n}^{\mathrm{o}} 353.147-\mathrm{DF}^{50}$

Assim, faz-se necessário contrapor os argumentos apresentados pelas teorias procedimentalistas e substancialistas ${ }^{51}$ quanto à atuação jurisdicional no âmbito da democracia deliberativa.

Dentre os autores que se adotam uma concepção democráticodeliberativa, Rawls se destaca como defensor de uma postura substancialista. Quanto à atuação da jurisdição constitucional, Rawls defende que apesar do judiciário ser contramajoritário, sua atuação é justificada quando suas decisões estão de acordo com a constituição. Assim, o judiciário é um dos fóruns da razão pública. ${ }^{52}$

A razão pública contrapõe-se às muitas razões não-públicas (articuladas no âmbito das igrejas, universidades, associações civis, família) e é característica de uma sociedade democrática. Tem como objeto o bem público, ou seja, aquilo que a concepção política de justiça requer da estrutura básica das instituições da sociedade. ${ }^{53}$

Para Rawls, somente valores políticos devem resolver questões fundamentais que envolvem elementos constitucionais essenciais. ${ }^{54}$ Reco-

\footnotetext{
47 SAMPAIO. A Constituição reinventada pela jurisdição constitucional, p. 92.

${ }^{48}$ Nesse sentido, Alexy enfatiza que o juiz deve atuar sem arbitrariedade e, portanto, sua decisão deve ser fundamentada em uma argumentação racional (ALEXY. Teoria da argumentação jurídica: a teoria do discurso racional como teoria da justificação jurídica, p. 53).

${ }^{49}$ A Corte Warren (1953-1969) teve a produção mais criativa da história da Suprema Corte norte-americana. Buscou significativas mudanças sociais. A decisão mais importante foi proferida em Brown v. Board of Education (1954), oportunidade em que se declarou a inconstitucionalidade da segregação racial predominante nas escolas públicas do Sul dos Estados Unidos. Contudo, há outras decisões importantes como Baker v. Carr (1962) na qual se discutiu a má ordenação dos distritos eleitorais e assentou-se que a ordenação dos distritos era matéria sujeita a revisão judicial. Sobre o tema: MORO. Jurisdição constitucional como democracia, p. 21-32.

${ }^{50}$ Trata-se de recurso provido para assegurar o direito de uma pessoa de ser tratada em Cuba em razão de retinose pigmentar (cegueira). A decisão baseou-se no direito à proteção a saúde do recorrente (BRASIL. Superior Tribunal de Justiça. Recurso especial n. 353.147-DF. Relator Ministro Franciulli Netto. Julgado em 15 out. 2002).

${ }^{51}$ Segundo Cláudio Pereira de Souza Neto há um consenso no âmbito da teoria democrático deliberativa quanto à cooriginariedade entre soberania popular e estado de direito e quanto ao caráter deliberativo da democracia. No entanto, para além disso, há muita discussão. A principal tem como objeto a questão de se a democracia deliberativa deve assumir um caráter procedimental ou substancial (SOUZA NETO. Teoria constitucional e democracia deliberativa: um estudo sobre o papel do direito na garantia das condições para a cooperação na deliberação democrática, p. 97).

${ }^{52}$ RAWLS. O liberalismo político, p. 262.
} 
nhece que muitas das questões públicas não são questões fundamentais (ex. previsão de fundos para museus, leis que regulam a propriedade) e, portanto, não devem necessariamente ser resolvidas através do uso da razão pública, embora isso seja desejável. ${ }^{55}$

O ideal de razão pública aplica-se apenas aos cidadãos quando atuam na argumentação política no fórum público. Também se aplica - e de forma especial - ao judiciário e, sobretudo, ao Supremo Tribunal numa democracia constitucional, pois deve justificar suas decisões na compreensão da constituição, de estatutos e precedentes relevantes. ${ }^{56}$

Rawls aponta que mesmo sendo o Supremo Tribunal o melhor intérprete da Constituição, deve-se reconhecer que o poder supremo é detido pelos três poderes, sendo cada qual responsável perante o povo. ${ }^{57}$ Ainda, acata a concepção dualista de Ackerman e fundamenta a legitimidade democrática do poder judiciário por ser responsável pela proteção da constituição (lei mais alta). ${ }^{58}$ Ao aplicar a razão pública, o judiciário deve evitar que seja corroída pela legislação das maiorias. ${ }^{59}$

$\mathrm{O}$ autor defende o ativismo judicial e afirma que o papel do judiciário não é meramente defensivo, mas também deve conferir uma existência apropriada e contínua à razão pública (única que o tribunal exerce). Mas note-se que Rawls não defende que a constituição é o que a Suprema Corte diz que é, mas sim o que o povo permitirá à corte dizer que ela é. ${ }^{60}$

A noção de que o Judiciário é um caso exemplar de razão pública

\footnotetext{
${ }^{53}$ RAWLS. O liberalismo político, p. 262.

${ }^{54}$ Os elementos constitucionais são de dois tipos: a) princípios fundamentais que especificam a estrutura geral do Estado e do processo político (prerrogativas do legislativo, do executivo e do judiciário, alcance da regra da maioria); b) os direitos e liberdades fundamentais e iguais que as maiorias legislativas devem respeitar (direito de voto, participação na política, liberdade de consciência, liberdade de pensamento e de associação e garantias do império da lei). Os dois elementos se diferem da seguinte forma: os primeiros especificam a estrutura geral do Estado e do processo político, ao passo que o segundo os direitos e liberdades dos cidadãos (RAWLS. O liberalismo político, p. 277-278).

${ }_{55}^{5}$ RAWLS. O liberalismo político, p. 264.

${ }^{56}$ Acrescente-se, ainda, que como os atos do legislativo e do executivo não precisam ser justificados dessa maneira, o papel especial do tribunal faz dele um caso exemplar de razão pública (RAWLS. O liberalismo político, p. 265).

${ }^{57}$ RAWLS. O liberalismo político, p. 283.

${ }^{58} \mathrm{E}$, assim, a teoria de Rawls pode ser submetida à mesma crítica. Ackerman distingue dois níveis de decisões fundamentais: as decisões constitucionais que são tomadas em momentos episódicos de intensa mobilização e as outras decisões que são tomadas pelos representantes do povo. Ao Judiciário caberia assegurar as decisões de primeiro nível. Contudo, sua teoria não oferece critérios seguros de identificação dos dois níveis de decisão e também não demonstra porque o Judiciário seria a instituição melhor capacidade para fazer a distinção e proteger as decisões constitucionais (GARGARELLA. La justicia frente al gobierno: sobre el carácter contramayoritario del poder judicial, p. 139-141).

${ }^{59}$ RAWLS. O liberalismo político, p. 284.
} 
é interessante para enfatizar o papel da jurisdição constitucional. Atua só no âmbito dos valores políticos que são objeto de consenso entre doutrinas abrangentes e razoáveis. Não tem liberdade para se basear em visões abrangentes como os cidadãos e mesmo os legisladores. Principalmente nesse ponto, embora a teoria de Rawls seja rotulada como substancialista, sua concepção não é totalmente incompatível com o procedimentalismo. ${ }^{61}$

Com efeito, há diversas concepções de procedimentalismo. ${ }^{62}$ Mas as idéias fundamentais são as seguintes: primeiro, que a conciliação do constitucionalismo e da democracia exige que se distribuam adequadamente as tarefas entre Legislativo e Judiciário $^{63}$ e, segundo, que não são possíveis teorias morais materiais, mas apenas teorias procedimentais que formulam regras ou condições de argumentação ou decisão prática racional. ${ }^{64}$

Assim, o papel do Judiciário (e também a justificativa do controle de constitucionalidade) seria promover e assegurar as condições democráticas. ${ }^{65}$ Conforme anota Nino, o reconhecimento do valor epistêmico da democracia deliberativa determina a crença na primazia do processo de discussão coletiva e de decisão majoritária sobre qualquer outro procedimento para determinar soluções moralmente aceitáveis. ${ }^{66}$

Mas isso não significa que a jurisdição constitucional não tenha

\footnotetext{
${ }^{60}$ RAWLS. O liberalismo político, p. 286-288.

${ }^{61}$ Até por que um dos marcos do procedimentalismo é a impossibilidade de sustentar valores metafísicos. Nesse ponto, coaduna-se com a proposta de Rawls. Ademais, verifica-se que Rawls inclusive define a justiça como equidade como uma forma de justiça procedimental pura (RAWLS. Uma teoria da justiça, p. 91-93). Não se está afirmando que não há diferença entre a teoria de Rawls e as teorias procedimentalistas, mas apenas que guardam alguns aspectos comuns.

62 Os dois principais autores são John Hart Ely e Jürgen Habermas. Procurando demonstrar a compatibilidade do controle de constitucionalidade com a democracia representativa, Ely sustentou que o tribunal deveria restringir-se a proteger o bom funcionamento do sistema democrático, sobretudo em manter abertos os canais de participação e comunicação pública, bem como se preocupar com o modo como as maiorias tratam as minorias (ELY. Democracia y desconfianza: una teoria del control constitucional). Já Habermas formula sua proposta no âmbito da democracia deliberativa. Sustenta que somente as condições processuais da gênese democrática das leis asseguram a legitimidade do direito. Assim, é possível encontrar um sentido para as competências da jurisdição constitucional que corresponde à intenção da divisão de poderes no interior do Estado de direito. Tais competências referem-se à proteção o sistema de direitos que possibilita a autonomia pública e privada dos cidadãos (HABERMAS. Direito e democracia: entre facticidade e validade, p. 326).

${ }^{63}$ SAMPAIO. A Constituição reinventada pela jurisdição constitucional, p. 92.

${ }^{64}$ ALEXY. Sistema jurídico, princípios y razón práctica, p. 22.

${ }^{65}$ Para Nino, o controle de constitucionalidade não é uma decorrência necessária da supremacia da Constituição. No âmbito da teoria epistêmica da democracia inclusive é posto em questão. No entanto, há três exceções. Duas baseadas nas condições que possibilitam que as decisões democráticas sejam confiáveis (controle do procedimento democrático e de leis que violam a autonomia pessoal) e a terceira baseia-se na condição que faz com que as decisões democráticas sejam eficazes (preservação da prática social moralmente aceitável). Note-se, porém, que Nino propôs sua teoria pressupondo um desenho institucional no qual os juízes têm uma conexão indireta com o processo democrático (NINO. La Constitución de la democracia deliberativa, p. 269-293).
} 
seu papel (ou que sua postura deve ser apenas de contenção), embora não seja o principal. Nesse sentido, é interessante e ilustrativa a consideração de Gustavo Binenbojm no sentido de que "assumindo que a democracia é um jogo, a Constituição seria um manual de regras e, os jogadores, os agentes políticos representantes do povo. À jurisdição constitucional, nesse contexto, cumpre o papel de ser o árbitro do jogo democrático". ${ }^{67}$

\section{Considerações finais}

No âmbito da teoria democrático-deliberativa, a constituição tem sua validade condicionada aos preceitos democráticos. A democracia, por sua vez, fundamenta-se em seu valor epistêmico, pois se trata de um bom método para alcançar o conhecimento moral e para produzir resultados que mais se aproximem do requisito da imparcialidade, o qual é imprescindível para conferir legitimidade às decisões em um contexto pluralista.

Entre as diversas formas de entender a democracia, a concepção deliberativa é que melhor assegura esse valor epistêmico à democracia. Trata-se de conceber a democracia como espaço de argumentação e justificação, priorizando-se, assim, o momento dialógico que antecede as decisões e que também as segue.

Entretanto, não significa renunciar à democracia representativa e majoritária. Nos termos da proposta de Nino, trata-se de um desvio pragmático necessário para conferir operatividade à democracia deliberativa.

Não se abandona também o instituto do controle de constitucionalidade. Embora a atuação da jurisdição constitucional seja problemática devido a sua carência de legitimidade democrática, tem-se que é necessária para resguardar e promover as condições da democracia deliberativa principalmente os direitos fundamentais que essa pressupõe.

Nesse ponto, discorda-se de Nino, para quem é contingente a existência do controle jurisdicional. A jurisdição constitucional é necessária e justificável na medida em que é exercida com base na razão pública.

Também não significa que a jurisdição constitucional seja o cenário principal da razão pública, como defende Rawls, mas que sua atuação

\footnotetext{
${ }^{66}$ NINO. La Constitución de la democracia deliberativa, p. 293.

${ }^{67}$ BINENBOJM. A nova jurisdição constitucional brasileira: legitimidade democrática e instrumentos de realização, p. 48.
} 
é legitima quando busca assegurar as condições que fazem parte de um consenso político, o que inclui os direitos e garantias fundamentais. Não é dado à jurisdição violar a autonomia privada impondo concepções perfeccionistas, mas lhe é devido tutelar a autonomia privada para que essas concepções não sejam impostas sequer pelos órgãos legislativo e executivo. Assim, defende-se que esse é o papel da jurisdição constitucional no âmbito de um regime democrático-deliberativo: atuar, com base na razão pública, para assegurar as condições da democracia deliberativa, não obstante a primazia seja das decisões cujo procedimento melhor respeite os pressupostos democrático-deliberativos.

\section{Referências}

ALEXY, Robert. Sistema jurídico, princípios y razón práctica. México: Fontamara, 2002.

ALEXY, Robert. Teoria da argumentação jurídica: a teoria do discurso racional como teoria da justificação jurídica. Tradução: Zilda Hutchinson Schild Silva. São Paulo: Landy, 2005.

BINENBOJM, Gustavo. A nova jurisdição constitucional brasileira: legitimidade democrática e instrumentos de realização. 2. ed. Rio de Janeiro: Renovar, 2004.

CITTADINO, Gisele. Pluralismo, direito e justiça distributiva: elementos da filosofia constitucional contemporânea. 3. ed. Rio de Janeiro: Lumen Juris, 2004.

CLÈVE, Clèmerson Merlin. A fiscalização abstrata da constitucionalidade no direito brasileiro. 2. ed. São Paulo: R. dos Tribunais, 2000.

DAHL, Robert. Um prefacio à teoria democrática. Tradução: Ruy Jungmann. Rio de Janeiro: Jorge Zahar, 1989.

ELY, John Hart. Democracia y desconfianza: una teoría del control constitucional. Tradução: Magdalena Holguín. Santafé de Bogotá: Siglo del Hombre, 1997.

GARGARELLA, Roberto. Constitución y democracia. In: ALBANESE, Susana; DALLA VIA, Alberto; GARGARELLA, Roberto et al. (Org.). Derecho constitucional. Buenos Aires: Ed. Universidad, 2004.

GARGARELLA, Roberto. La justicia frente al gobierno: sobre el carácter contramayoritario del poder judicial. Barcelona: Ariel, 1996.

HABERMAS, Jürgen. Direito e democracia: entre facticidade e validade. 2. ed. Tradução: Flavio Beno Siebeneichler. Rio de Janeiro: Tempo brasileiro, 2003. v. 1.

MORO, Sergio Fernando. Jurisdição constitucional como democracia. 2002. Tese (Doutorado em Direito do Estado) - Setor de Ciências Jurídicas, Universidade Federal do Paraná, Curitiba, 2002.

MOUfFE, Chantal. O regresso do político. Tradução: Ana Cecília Simões. Lisboa: Gradiva, 1996.

MUELLER, Friedrich. Quem é o poro? A questão fundamental da democracia. Tradução: Peter Naumann. 3. ed. São Paulo: Max Limonad, 2000. 
NINO, Carlos Santiago. Ética y derechos humanos: un ensayo de fundamentación. Barcelona: Ariel, 1989.

NINO, Carlos Santiago. La Constitución de la democracia deliberativa. Barcelona: Gedisa, 1999.

RAWLS, John. O liberalismo político. São Paulo: Ática, 2000.

RAWLS, John. Uma teoria da justiça. Trad. Almiro Pisetta e Lenita Esteves. São Paulo: Martins Fontes, 1997.

SAMPAIO, José Adércio Leite. A Constituição reinventada pela jurisdição constitucional. Belo Horizonte: Del Rey, 2002.

SOUZA NETO, Cláudio Pereira de. Teoria constitucional e democracia deliberativa: um estudo sobre o papel do direito na garantia das condições para a cooperação na deliberação democrática. Rio de Janeiro: Renovar, 2006.

SUNSTEIN, Cass. Prefacio. In: GARGARELLA, Roberto. La justicia frente al gobierno: sobre el carácter contramayoritario del poder judicial. Barcelona: Ariel, 1996.

Informação bibliográfica deste texto, conforme a NBR 6023:2002 da Associação Brasileira de Normas Técnicas (ABNT):

KROL, Heloísa da Silva. Democracia deliberativa e jurisdição constitucional. A\&C Revista de Direito Administrativo e Constitucional, Belo Horizonte, ano 7, n. 28, p. 151-165, abr./ jun. 2007. 